\title{
Deficiency of Growth Hormone-Releasing Hormone Signaling Is Associated with Sleep Alterations in the Dwarf Rat
}

\author{
Ferenc Obál Jr, ${ }^{1,2}$ Jidong Fang,, ${ }^{2}$ Ping Taishi,, ${ }^{2}$ Balint Kacsóh, ${ }^{3}$ Janos Gardi, ${ }^{2}$ and James M. Krueger ${ }^{2}$ \\ ${ }^{1}$ Department of Physiology, University of Szeged, Albert Szent-Györgyi Medical Center, 6720 Szeged, Hungary, \\ 2Department of Veterinary and Comparative Anatomy, Pharmacology and Physiology, Washington State University, \\ Pullman, Washington 99164-6520, and ${ }^{3}$ Division of Basic Medical Sciences and Department of Pediatrics, Mercer \\ University School of Medicine, Macon, Georgia 31207
}

\begin{abstract}
The somatotropic axis, and particularly growth hormonereleasing hormone $(\mathrm{GHRH})$, is implicated in the regulation of sleep-wake activity. To evaluate sleep in chronic somatotropic deficiency, sleep-wake activity was studied in dwarf $(d w / d w)$ rats that are known to have a defective GHRH signaling mechanism in the pituitary and in normal Lewis rats, the parental strain of the $d w / d w$ rats. In addition, expression of $\mathrm{GHRH}$ receptor (GHRH-R) mRNA in the hypothalamus/preoptic region and in the pituitary was also determined by means of reverse transcription-PCR, and GHRH content of the hypothalamus was measured. Hypothalamic/preoptic and pituitary GHRH-R mRNA levels were decreased in the $d w / d w$ rats, indicating deficits in the central GHRHergic transmission. Hypothalamic $\mathrm{GHRH}$ content in $d w / d w$ rats was also less than that found in Lewis rats. The $d w / d w$ rats had less spontaneous nonrapid eye
\end{abstract}

Pituitary growth hormone $(\mathrm{GH})$ stimulates protein anabolism and tissue growth. GH deficiency causes dwarfism in growing individuals. The effects of $\mathrm{GH}$ are mediated in part via insulinlike growth factor-1 (IGF-1). The synthesis and release of GH are mainly controlled by two hypothalamic neurohormones, GHreleasing hormone $(\mathrm{GHRH})$ and somatostatin; the latter inhibits secretion of GH. GH and IGF-1 feedback to inhibit secretory activities of GHRH and GH and to stimulate somatostatin (for review, see Müller et al., 1999). Sleep and the activity of the somatotropic axis are intimately related. A major burst of $\mathrm{GH}$ secretion occurs during deep nonrapid eye movement sleep (NREMS) in humans, and NREMS and GH secretion also correlate in various animal species (for review, see van Cauter and Plat, 1998). Hormones of the somatotropic axis are capable of modulating sleep. GHRH displays the best-documented sleeppromoting activity. NREMS increases after GHRH is injected into the cerebral ventricles (Ehlers et al., 1986; Nistico et al., 1987; Obál et al., 1988), into the medial preoptic area in rats

\footnotetext{
Received Dec. 4, 2000; revised Jan. 22, 2001; accepted Feb. 1, 2001.

This work was supported in part by National Institutes of Health Grants NS27250 and HD36520 to J.M.K., the Hungarian Ministry of Health and Science Foundation Grants ETT 04/033/2000 and OTKA-030456 to F.O., and a grant by the Medcen Foundation of the Medical Center of Central Georgia to B.K.

Correspondence should be addressed to Dr. James M. Krueger, Washington State University, College of Veterinary Medicine, Department of Veterinary and Comparative Anatomy, Pharmacology and Physiology, P.O. Box 646520, Pullman, WA 99164-6520. E-mail: krueger@vetmed.wsu.edu.

Dr. Gardi's present address: Endocrine Unit, University of Szeged, Albert SzentGyörgyi Medical Center, 6720 Szeged, Hungary.

Copyright (C) 2001 Society for Neuroscience $0270-6474 / 01 / 212912-07 \$ 15.00 / 0$
}

movement sleep (NREMS) (light and dark period) and rapid eye movement sleep (REMS) (light period) than did the control Lewis rats. After $4 \mathrm{hr}$ of sleep deprivation, rebound increases in NREMS and REMS were normal in the $d w / d w$ rat. As determined by fast Fourier analysis of the electroencephalogram (EEG), the sleep deprivation-induced enhancements in EEG slow-wave activity in the $d w / d w$ rats were only one-half of the response in the Lewis rats. The results are compared with sleep findings previously obtained in $\mathrm{GHRH}$-deficient transgenic mice. The alterations in NREMS are attributed to the defect in $\mathrm{GHRH}$ signaling, whereas the decreases in REMS might result from the growth hormone deficiency in the $d w / d w$ rat.

Key words: sleep; GHRH receptor; dwarf; sleep deprivation; somatotropic axis; rats

(Zhang et al., 1999b), or systemically (Steiger et al., 1992; Kerkhofs et al., 1993; Marshall et al., 1999; Obál et al., 1996), and in response to GHRH-containing nasal spray (Perras et al., 1999). NREMS decreases when GHRH is inhibited by means of a competitive receptor antagonist (Obál et al., 1991) or by the activation of the negative feedback in the somatotropic axis, e.g., after high doses of GH (Mendelson et al., 1980), IGF-1 (Obál et al., 1999), or after somatostatinergic stimulation (Frieboes et al., 1997; Beranek et al., 1999). Hypothalamic GHRH contents (Gardi et al., 1999a) and GHRH mRNA levels (Zhang et al., 1999a) display sleep-related variations. Collectively, these findings suggest that GHRH simultaneously promotes NREMS and GH secretion.

Little is known, however, about how sleep is altered in chronic GHRH deficiency. An autosomal recessive mutation in the Lewis rats is associated with selective GH deficiency and consequent dwarfism (Charlton et al., 1988). In adult dwarf $(d w / d w)$ rats, plasma concentration of $\mathrm{GH}, \mathrm{GH}$ content of the pituitary, and GH and cAMP responses to GHRH are greatly decreased (Charlton et al., 1988; Carmignac and Robinson, 1990; Downs and Frohman, 1991). GHRH receptor (GHRH-R) mRNA levels are reduced in the pituitary of $d w / d w$ rats (Carmignac et al., 1996; Zeitler et al., 1998). The signal transduction pathway might also be affected distal to the receptor protein (Brain et al., 1991; Downs and Frohman, 1991). Secretions of pituitary hormones other than $\mathrm{GH}$ are normal in the $d w / d w$ rat, albeit prolactin secretion might be enhanced (Kineman et al., 1989). Hypothalamic production of GHRH is not impaired in the $d w / d w$ rats; in 
fact, GHRH release might be enhanced because of the lack of GH- and/or IGF-1-induced negative feedback (Mizobuchi et al., 1991; Pellegrini et al., 1997).

The aim of our experiments was to characterize hypothalamic GHRH-R mRNA levels, spontaneous sleep, and the sleep response to sleep deprivation in the $d w / d w$ rats. Preliminary observations indicated that NREMS and GHRH-R mRNA are in fact altered in these rats (Krueger et al., 1999).

\section{MATERIALS AND METHODS}

Animals. Male, age-matched ( $\sim$-month-old) normal Lewis $(n=9)$ and $d w / d w(n=14)$ rats were used. The body weight of the $d w / d w$ rats $(216 \pm$ $3.4 \mathrm{gm})$ was $40 \%$ less than that of the Lewis rats $(360 \pm 2.5 \mathrm{gm})$. For surgery, the rats were anesthetized with ketamine-xylazine (87 and 13 $\mathrm{mg} / \mathrm{kg}$, respectively), and stainless-steel screws for electroencephalogram (EEG) recording were implanted over the frontal and parietal cortices and over the cerebellum. Electromyogram (EMG) electrodes were inserted into the dorsal neck muscles. A thermistor placed over the parietal cortex served to measure brain cortical temperature (Tcrt).

Recording. The rats were housed in individual Plexiglas cages placed in environmental chambers, with a $12 \mathrm{hr}$ light/dark cycle. The ambient temperature was $26 \pm 1^{\circ} \mathrm{C}$. Food and water were available ad libitum. After surgery, the rats were connected to the recording tether and habituated to the experimental conditions for 8-10 d. The tethers were attached to commutators, and cables from the commutators were connected to amplifiers. The signals were digitized (128 Hz sampling rate) and collected by a computer and stored on compact discs. For scoring, the EEG, EMG, and Tcrt were restored on the computer screen. In addition, power density values were calculated by fast Fourier transformation for consecutive $10 \mathrm{sec}$ epochs in the frequency range of $0.25-40.0$ $\mathrm{Hz}$ for $0.5 \mathrm{~Hz}$ bands. The power density spectra were also displayed on the computer screen. The states of vigilance were determined over $10 \mathrm{sec}$ epochs by the usual criteria as NREMS (high-amplitude EEG slow waves, low-tone muscle activity, and declining Tcrt upon entry), rapid eye movement sleep (REMS) (highly regular theta EEG activity, loss of muscle tone with occasional twitches, and a rapid rise in Tcrt at onset), and wakefulness (EEG activities similar to but often less regular and with lower amplitude than those in REMS, high EMG activity, and a gradual increase in Tcrt after arousal). The percentage of the time spent in each state of vigilance over $1 \mathrm{hr}$ periods was determined. The $10 \mathrm{sec}$ Tcrt values were averaged for $1 \mathrm{hr}$ periods. Mean power density spectra were calculated for $10 \mathrm{sec}$ uninterrupted periods of artifact-free NREMS in each hour. The power density values for the $0.5-4 \mathrm{~Hz}$ (delta) frequency range were integrated and used as an index of EEG slow-wave activity (SWA) during NREMS to characterize sleep intensity in each recording hour.

Experimental schedule. After habituation, the sleep-wake activity of rats was recorded for 3 consecutive days starting at light onset. Each day, the recorded data were backed up on compact discs in the last hour of the dark period, and therefore, data from this hour was discarded. The rats were sleep-deprived on day 4 during the first $4 \mathrm{hr}$ of the light period. The rats were also recorded from during and after sleep deprivation for the rest of the light period (hours 5-12) and during the subsequent dark period. Sleep deprivation was performed by gentle handling while the rats stayed in their home cage; whenever behavioral or EEG signs of sleep were observed, the rats were aroused by knocking on the cage or touching them.

Determination of $G H R H-R m R N A$. After the termination of the sleep recording, the rats were killed by guillotine between hours 3 and 6 after light onset. The pituitary was harvested, and hypothalamus/preoptic region (landmarks of frontal edge of the optic chiasma, lateral sulci, mammillary bodies, and a depth of $2 \mathrm{~mm}$ ) was dissected within 1 min of death, and the RNA was extracted and stored at $-70^{\circ} \mathrm{C}$ until use. GHRH-R mRNA levels were determined in the pituitaries obtained from eight Lewis and seven $d w / d w$ rats, and in the hypothalami collected from nine Lewis and eight $d w / d w$ rats.

Reverse transcription (RT)-PCR was used to measure GHRH-R mRNA. For extraction, the tissue samples were homogenized in $1 \mathrm{ml}$ of RNA STAT-60 (TelTest "B," Friendwood, TX). The amounts of RNA were determined by measuring the optical densities of the samples measured at $\lambda=260$. The integrity of the RNA was monitored by running aliquots in formaldehyde-agarose gels. First-strand cDNA was synthesized with oligo-dT priming and Superscript II (Life Technologies,
Gaithersburg, MD) from each hypothalamus sample using $5 \mu \mathrm{g}$ of total RNA, and from each pituitary using $2 \mu \mathrm{g}$ of total RNA. The cDNA was stored at $-20^{\circ} \mathrm{C}$ until used.

The linear region for the cycles of PCR signal amplification was determined. For this, amplifications for GHRH-R mRNA and glyceraldehyde-3-phosphate dehydrogenase (GAPDH) mRNA (see below) were calculated from densitometric measurements of the ethidium bromide-stained agarose gels and plotted on a logarithmic scale against the cycle number. The cDNA ( $4 \mu \mathrm{l}$ for the hypothalamus and $1 \mu \mathrm{l}$ for the pituitary) was amplified by PCR $\left(27\right.$ cycles of $94^{\circ} \mathrm{C}$ for $1 \mathrm{~min}, 58^{\circ} \mathrm{C}$ for 1 min, and $72^{\circ} \mathrm{C}$ for $2 \mathrm{~min}$; last cycle, $72^{\circ} \mathrm{C}$ for $7 \mathrm{~min}$; and 32 and 19 cycles for GHRH-R and GAPDH, respectively) in a volume of $25 \mu \mathrm{l}$ using 0.25 $\mu \mathrm{l} /$ tube (1.25 U/tube) Taq polymerase. The concentrations of the primers, the dNTP, and $\mathrm{MgCl}_{2}$ were $0.4 \mu \mathrm{M}, 0.2 \mathrm{mM}$, and $1.5 \mathrm{~mm}$, respectively. The GHRH-R mRNA levels were expressed with respect to GAPDH mRNA as a standard. The number of cycles chosen was in the linear range for both GHRH-R cDNA and GAPDH cDNA under these conditions. The sequences of the primers used were as follows: GHRH-R sense, 5'-ccaaaccagctttctggtggc-3'; GHRH-R antisense, 5'-ggcctagcactcagaggtgag-3' (position, 13O2-1282); GAPDH sense, 5' -gatgctggtgctgagtatgtcg-3'; and GAPDH antisense, 5'-gtggtgcaggatgcattgctga-3'. The primers for GHRH-R mRNA correspond to those reported by Takahashi et al. (1995) and potentially amplify both the short and the long isoforms of GHRH-R mRNA described by Mayo (1992) in the rat pituitary. The resulting PCR products $(10 \mu \mathrm{l}$ of GHRH-R and $5 \mu \mathrm{l}$ of GAPDH) were loaded onto $2 \%$ agarose gels containing ethidium bromide $(0.5 \mu \mathrm{g} / \mathrm{ml})$. Densitometric analysis was performed by NIH Image 1.54 for onedimensional gels (Fig. 1). The band containing the GHRH-R PCR product in the pituitary of a Lewis rat was extracted from the gel and sequenced by the Department of Biochemistry from Washington State University (Pullman, WA).

Measurement of hypothalamic GHRH content. The frozen samples from groups of rats not included in the sleep studies $(n=8$ for dw/dw and $n=$ 6 for Lewis rats) were weighed and then boiled for $5 \mathrm{~min}$ in $0.5 \mathrm{ml}$ of 2 $\mathrm{M}$ acetic acid (Katakami et al., 1986). The tissues were individually homogenized with ultrasound. The homogenates were centrifuged at $15,000 \times g$ for $20 \mathrm{~min}$ at $4^{\circ} \mathrm{C}$, aliquots were taken for protein measurement (Bradford, 1976), and the rest of each supernatant was lyophilized for radioimmunoassay. The recovery of the GHRH from extracts was $70-75 \%$. The GHRH kit was purchased from Peninsula Laboratories (Belmont, CA) (standard, rat GHRH-43). According to the supplier, the antiserum to rat GHRH exhibited $100 \%$ cross-reactivity with human GHRH, whereas it did not recognize the following peptides: His ${ }^{1}, \mathrm{Nle}^{27}$ GHRH 1-32, porcine GHRH, human parathyroid hormone 1-34, rat peptide histidine isoleucine, and human, rat, porcine vasoactive intestinal peptide. The peptide was measured in triplicate. The lower limit of assay detection was $8 \mathrm{pg} / \mathrm{tube}$, and the intra-assay and interassay coefficients of variation were 4.5 and 5.0, respectively.

Statistics. Data (hourly values of the states of vigilance, SWA during NREMS, and Tcrt) obtained on the $3 \mathrm{~d}$ of undisturbed recording were averaged to characterize spontaneous sleep-wake activity in the normal Lewis rats and $d w / d w$ rats. These variables during the light and dark periods were compared by means of two-way ANOVA between the two groups. The group effects (independent samples) and the time effects (repeated measures) were the two factors of the ANOVA. ANOVA was also used to evaluate the effects of sleep deprivation on the sleep parameters and Tcrt within each group and to compare the sleep deprivation-induced changes in these variables between groups. Because diurnal variations in sleep and Tcrt are well known, only the group effects are discussed herein, and $F$ statistics for variations in time are not presented. There are hours within which sleep does not appear at night in the rat; therefore, the mean values of SWA during NREMS were calculated for the $11 \mathrm{hr}$ recording period in the dark and were used for statistical analysis performed by $t$ tests (paired for intragroup and unpaired for intergroup comparisons). Mean relative optical densities of the GHRH-R PCR products and the GHRH peptide contents of the hypothalamus were compared by means of Student's $t$ test between the Lewis and the $d w / d w$ rats. An $\alpha$ level of $p<0.05$ was considered to be significant in all tests.

\section{RESULTS}

\section{GHRH-R mRNA and GHRH content}

Amplification of GHRH-R mRNA by PCR resulted in a single product in both the hypothalamus and the pituitary in Lewis and 

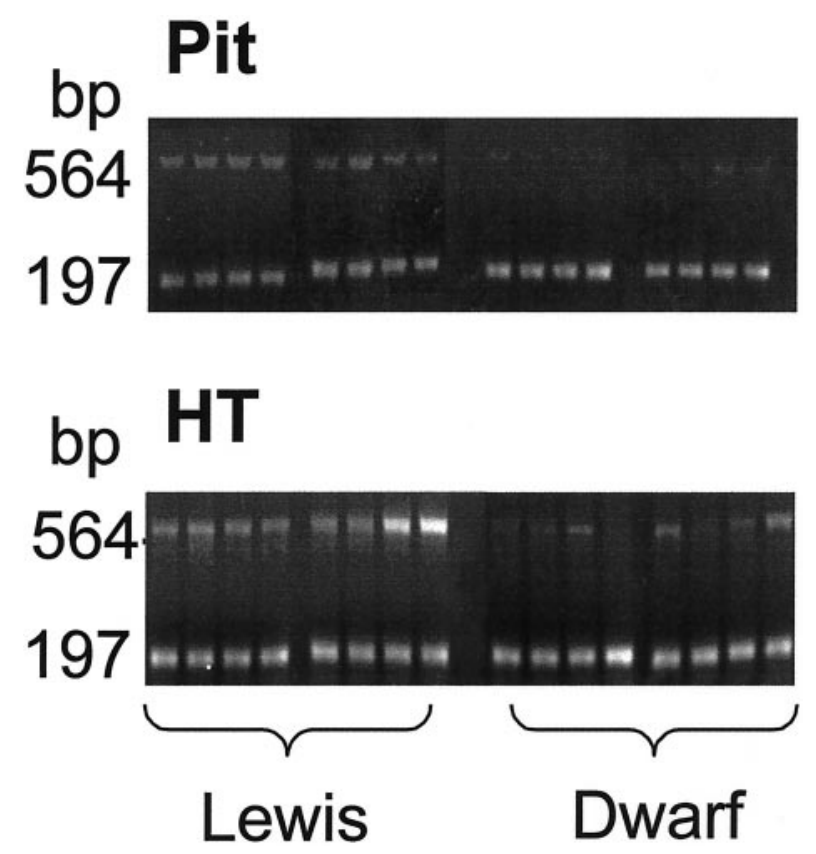

Figure 1. Gel electrophoresis and the ethidium bromide staining of RT-PCR amplified GHRH-R (564 bp) and GAPDH (197 bp) mRNA in the hypothalamus/preoptic area (bottom) and the pituitary (top) in Lewis (left) and $d w / d w(r i g h t)$ rats. The expression of GHRH-R mRNA relative to GAPDH mRNA in $d w / d w$ rats is less than that observed in Lewis rats. Figure 2 provides the quantitative analysis of these results.

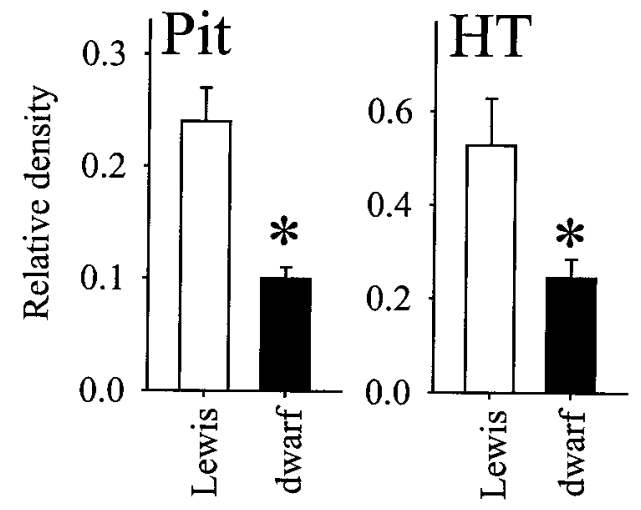

Figure 2. Mean \pm SE levels of GHRH-R mRNA levels in the pituitary (top; Lewis, $n=8 ; d w / d w, n=8$ ) and in the hypothalamus/preoptic region (bottom; Lewis, $n=8 ; d w / d w, n=8$ ). The levels of GHRH-R mRNA are expressed with respect to the intensity of GAPDH mRNA determined in the same assay for each rat. Asterisks denote significant differences (Student's $t$ test, two-tailed).

$d w / d w$ rats (Fig. 1). The electrophoretic mobility of the transcripts did not differ between the groups. Sequencing of the amplified product from the pituitary of a Lewis rat indicated that it corresponded to the short form of the GHRH-R. The expression level of GHRH-R transcript (determined as the GHRH-R/GAPDH ratio) in the $d w / d w$ rats was $\sim 20-65 \%$ lower than in normal Lewis rats (Fig. 2). The difference between groups was statistically significant in both samples (pituitary, $t=4.89$; hypothalamus, $t=2.27$; $p<0.05$ for both). The GHRH peptide content in the hypothalamus of the $d w / d w$ rats $(1825.8 \pm 172.5 \mathrm{pg} / \mathrm{mg}$ protein) was only one-half of that found in normal Lewis rats $(3708.1 \pm 312.6)$. This difference between the $d w / d w$ and the Lewis rats was also statistically significant $(t=5.63 ; p<0.05)$.

\section{Spontaneous sleep}

The $d w / d w$ rats did not display any motor abnormalities; their behavior seemed to be normal. Sleep-wake activity in Lewis rats and the dwarfs exhibited diurnal rhythms, with sleep and wakefulness occurring predominantly during the light and the dark periods of the day, respectively (Fig. 3). The amounts of NREMS were highest in the first portion of the light period, whereas REMS peaked in the afternoon. EEG SWA during NREMS was intense in the morning, and then it declined progressively throughout the light period and increased at night. Tcrt was relatively low during the day and increased at night.

The $d w / d w$ rats spent less time in NREMS during both the light period $\left(F_{(1,21)}=21.59\right)$ and the dark period $\left(F_{(1,21)}=18.6\right)$ than the normal Lewis rats (Fig. 3, Table 1). The differences in the amounts of NREMS between the groups varied with time (light, $F_{(11,231)}=2.12$; dark, $\left.F_{(10,210)}=4.58\right)$. NREMS was normal during the first $3 \mathrm{hr}$ of the light period in the $d w / d w$ rats and decreased thereafter. Compared with Lewis rats, the $d w / d w$ rats exhibited significantly less NREMS bouts lasting longer than 4 $\min (d w / d w, 16.3 \pm 0.97$ vs Lewis, $28.8 \pm 1.20 ; t=8.15 ; p<0.05)$ and more short NREMS bouts $(d w / d w, 138.7 \pm 3.56$ vs Lewis, $104.2 \pm 4.62 ; t=5.97 ; p<0.05)$. At night, two periods of increased NREMS occurred when the amounts of NREMS in Lewis rats greatly exceeded NREMS in the $d w / d w$ rats. The number of long NREMS bouts decreased significantly in the $d w / d w$ rats $(d w / d w, 3.4 \pm 0.83$ vs Lewis, $7.5 \pm 1.09 ; t=3.03 ; p<$ $0.05)$, whereas the number of short NREMS bouts did not differ between the groups at night. Absolute values of EEG SWA during NREMS revealed high interindividual variations in both groups, but they were in the same range (Fig. 3).

The $d w / d w$ rats spent significantly less time in REMS than the Lewis rats during the light period $\left(F_{(1,21)}=32.94\right)$. This difference occurred between hours 5 and 12 of the light period when normal Lewis rats exhibited the highest amounts of REMS (Fig. 3). The $d w / d w$ rats had significantly fewer REMS bouts longer than 2 min than the Lewis rats $(d w / d w, 17.7 \pm 1.57$ vs Lewis, $24.1 \pm 1.35 ; t=2.83 ; p<0.05)$, but the number of short REMS bouts did not differ. At night, REMS was low in both groups without significant differences between them. Also in the dark period, the number of REMS bouts longer than 2 min was slightly, albeit significantly, less in the $d w / d w$ rats than in the Lewis rats $(d w / d w, 6.9 \pm 0.50$ vs Lewis, $9.5 \pm 0.78 ; t=2.94 ; p<0.05)$, but this loss in time spent in REMS was compensated by a strong tendency to a higher number of short REMS bouts $(d w / d w, 20.1 \pm$ 1.97 vs Lewis, $15.7 \pm 0.94$; not significant).

There were no differences in Tcrt between the control Lewis rats and the dwarf rats.

\section{Responses to sleep deprivation}

The time spent in NREMS increased greatly after sleep deprivation in both groups of rats (Fig. 4). Increases in NREMS were significant during both the light period (Lewis, $F_{(1,8)}=282.41$; $d w / d w, F_{(1,13)}=100.34$ ) and the dark period (Lewis, $F_{(1,8)}=$ $\left.11.53 ; d w / d w, F_{(1,13)}=17.40\right)$. EEG SWA during NREMS was enhanced during the light period after sleep deprivation in Lewis rats (Lewis, $\left.F_{(8,1)}=53.6\right)$ and $d w / d w$ rats $\left(F_{(13,1)}=20.0\right)$. These EEG SWA responses peaked in hour 1 after deprivation and declined progressively thereafter in both groups (Fig. 4). EEG SWA tended to drop below baseline during the night after deprivation. Calculated for the entire dark period after deprivation, suppression of EEG SWA was significant in the $d w / d w$ rats $(t=$ 
Table 1. Amounts (mean \pm SE) of spontaneous NREMS and REMS and the effects of sleep deprivation on NREMS, REMS, and EEG SWA during NREMS in Lewis and $d w / d w$ rats

\begin{tabular}{|c|c|c|c|c|}
\hline & \multicolumn{2}{|l|}{ Light } & \multicolumn{2}{|l|}{ Dark } \\
\hline & Lewis & $d w / d w$ & Lewis & $d w / d w$ \\
\hline Spontaneous NREMS ${ }^{a}$ & $49.1 \pm 1.05$ & $41.2 \pm 0.85^{*}$ & $21.3 \pm 0.54$ & $16.0 \pm 0.98^{*}$ \\
\hline Spontaneous REMS ${ }^{a}$ & $14.4 \pm 0.53$ & $10.0 \pm 0.47^{*}$ & $6.4 \pm 0.38$ & $5.5 \pm 0.38$ \\
\hline NREMS after $\mathrm{SD}^{b}$ & $59.3 \pm 1.24$ & $50.1 \pm 1.22 *$ & $26.0 \pm 1.46$ & $19.2 \pm 1.33^{*}$ \\
\hline REMS after $\mathrm{SD}^{b}$ & $16.9 \pm 0.41$ & $10.8 \pm 0.54^{*}$ & $11.1 \pm 0.68$ & $8.5 \pm 0.63^{*}$ \\
\hline Changes in NREMS after $\mathrm{SD}^{b}$ & $+12.4 \pm 0.69$ & $+13.7 \pm 1.32$ & $+4.2 \pm 1.15$ & $+3.2 \pm 1.74$ \\
\hline Changes in REMS after $\mathrm{SD}^{b}$ & $-0.2 \pm 0.52$ & $-0.2 \pm 0.75$ & $+4.7 \pm 0.96$ & $+3.0 \pm 0.59$ \\
\hline Changes in SWA after $\mathrm{SD}^{b}$ & $+82.7 \pm 8.29$ & $+39.3 \pm 7.73^{*}$ & $+1.8 \pm 4.91$ & $-15.3 \pm 3.31^{*}$ \\
\hline
\end{tabular}

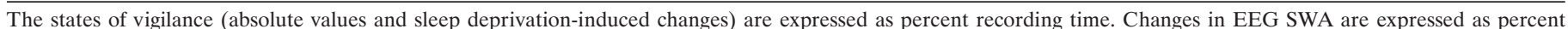

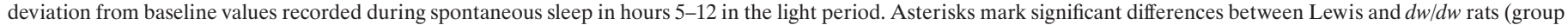
effects in ANOVA; $p<0.05)$. SD, Sleep deprivation.

${ }^{a}$ Amounts of spontaneous NREMS and REMS are provided for the $12 \mathrm{hr}$ light period.

${ }^{b}$ Values in the light period after sleep deprivation refer to hours 5-12 of the light period.

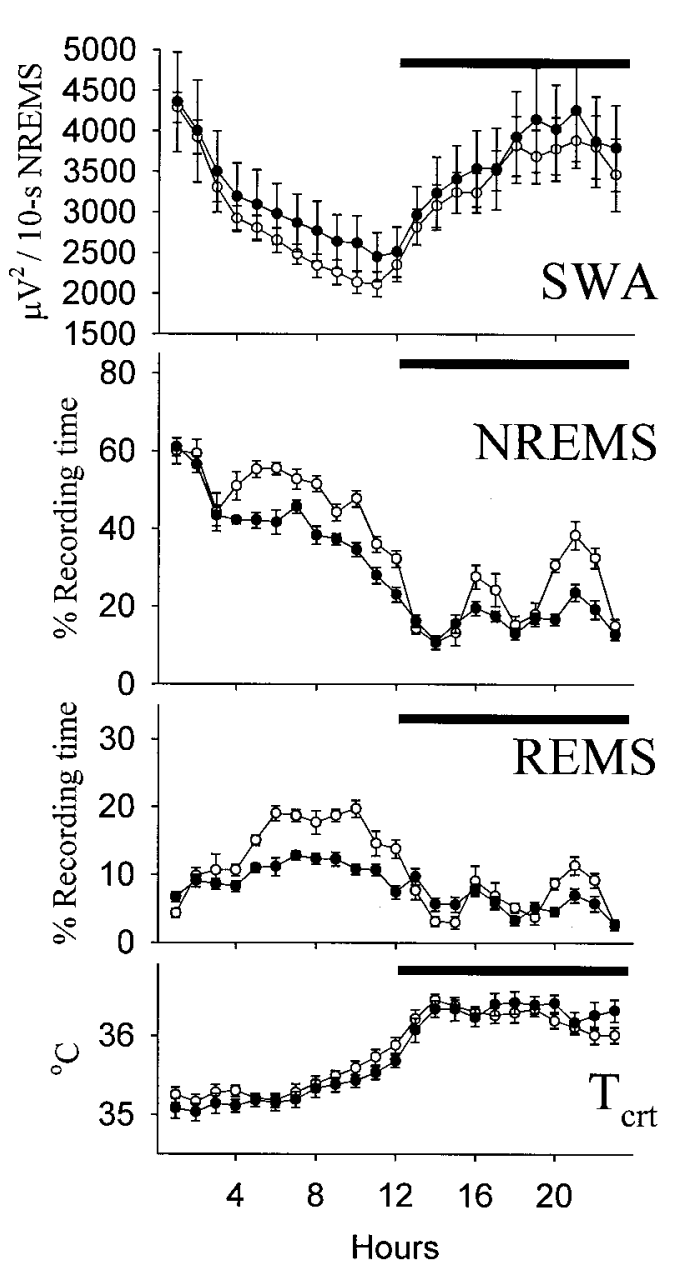

Figure 3. Hourly values (mean \pm SE) of NREMS, REMS, Tcrt, and EEG slow-wave activity during NREMS (SWA, integrated power densities in the delta range) in Lewis (open symbols; $n=9$ ) and $d w / d w$ (filled symbols; $n=14$ ) rats. Significant differences were obtained in the amounts of NREMS (light and dark periods) and REMS (light period) between the $d w / d w$ and Lewis rats (ANOVA; see Table 1 and Results), whereas SWA and Tcrt did not differ. Horizontal bars indicate dark period.

4.51), but it did not reach the level of statistical significance in the Lewis rats.

Increases in REMS after sleep deprivation were delayed until the last hour of the light period and the subsequent dark period in both groups (Fig. 4). Calculated for hours 5-12 of the light period, the changes were not significant (Table 1). REMS increased significantly during the first postdeprivation night in the control Lewis and the dwarf groups (Lewis, $F_{(1,8)}=20.84 ; d w / d w, F_{(1,13)}$ $=24.83)$. Tcrt increased significantly during the $4 \mathrm{hr}$ period of sleep deprivation in both groups (Lewis, $F_{(1,8)}=429.58 ; d w / d w$, $\left.F_{(1,13)}=159.46\right)$. Tcrt tended to decrease slightly after deprivation, but these changes did not reach the level of statistical significance.

The absolute values of NREMS during recovery were significantly higher in the Lewis rats than in the dwarfs during recovery (hours 5-12 in light, $F_{(1,21)}=23.55$; dark, $\left.F_{(1,21)}=10.29\right)$. These differences, however, followed the differences between the two groups in the amounts of spontaneous NREMS on the baseline day, and the deprivation-induced changes in NREMS were not different between the two groups during either the light or the dark period (Table 1). Similarly, Lewis rats exhibited more REMS than the $d w / d w$ rats after sleep deprivation (hours 5-12 in light, $F_{(1,21)}=51.88$; dark, $\left.F_{(1,21)}=6.44\right)$, but the increments in REMS with respect to baseline were the same in both groups (Table 1). The EEG SWA response to sleep deprivation was the sleep parameter that made the distinction between the groups (Table 1). The sleep deprivation-induced enhancements in EEG SWA in the $d w / d w$ rats were only one-half of those observed in the Lewis rats $\left(F_{(1,21)}=12.51\right)$, and at night, EEG SWA diminished significantly more in the $d w / d w$ rats than in normal Lewis rats $\left(F_{(1,21)}=7.81\right)$.

Although Lewis rats tended to exhibit higher Tcrt than the $d w / d w$ rats during sleep deprivation, the increments in Tcrt did not differ significantly between the two groups.

\section{DISCUSSION}

A short and a long GHRH-R mRNA species have been described in the pituitary of the rat (Lin et al., 1992; Mayo, 1992). The short isoform is the predominant transcript, and recombinant receptors of only the short transcript mediate cAMP responses to GHRH (Miller et al., 1999). A shorter $(\alpha)$ and a longer $(\beta)$ subtype of the short isoform have been distinguished; both are functional when expressed in host cells (Zeitler et al., 1998). Significant decreases in the levels of GHRH-R mRNA were reported previously in the pituitary of $d w / d w$ rats (Carmignac et al., 1996; Zeitler et al., 1998), and the current results confirmed these observations. Findings in our laboratory suggest that GHRH binding is almost 


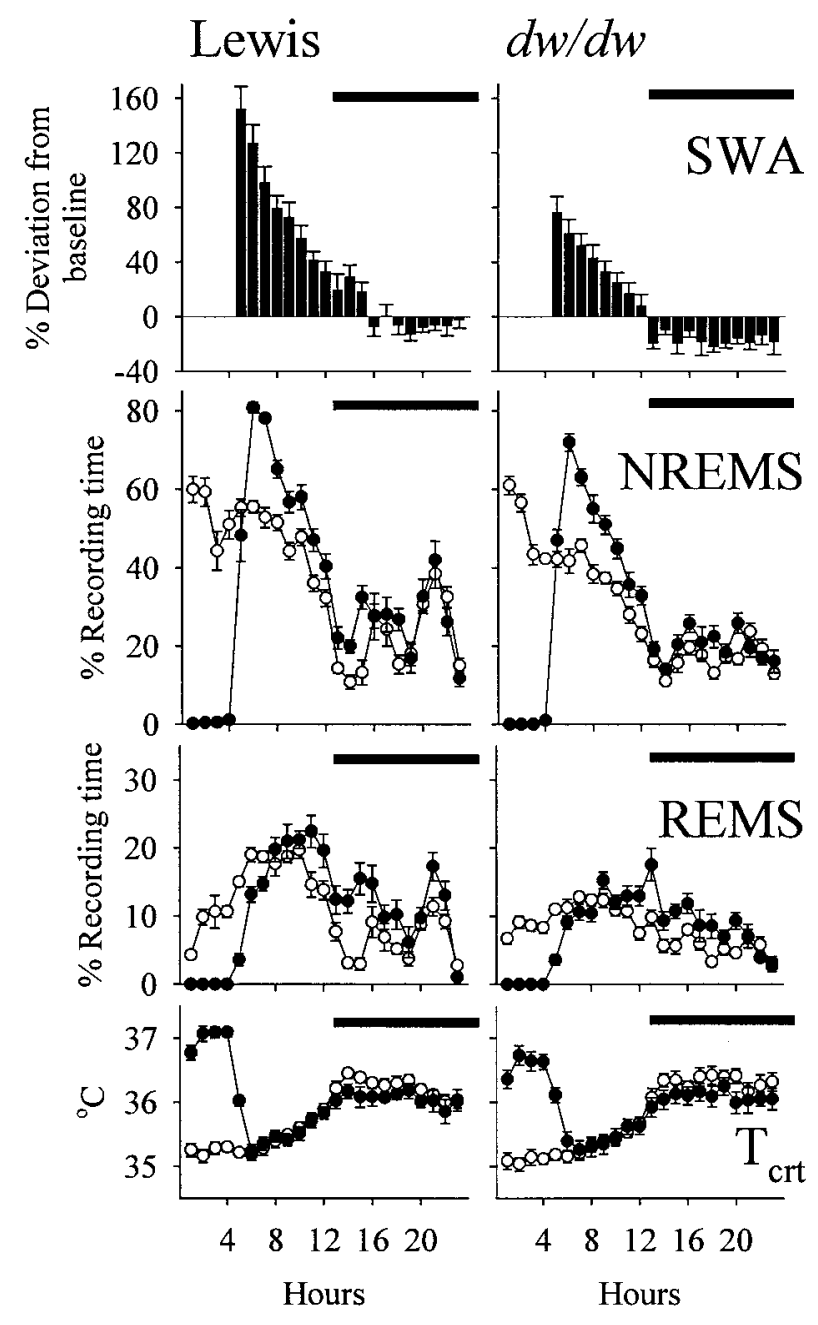

Figure 4. Responses (mean $\pm \mathrm{SE}$ ) to $4 \mathrm{hr}$ of sleep deprivation in Lewis (left; $n=9)$ and $d w / d w(r i g h t ; n=14)$ rats. Sleep deprivation occurred during the first $4 \mathrm{hr}$ of the light period. For both groups, baseline values of NREMS, REMS, and Tcrt are indicated by open symbols, whereas values during and after sleep deprivation are shown by filled symbols. EEG SWA during NREMS is shown as percent deviation from baseline values recorded during spontaneous NREMS. Significant differences between the Lewis and $d w / d w$ rats were observed in the SWA responses to sleep deprivation during both the light and the dark periods (ANOVA; see Table 1 and Results). Horizontal bars indicate dark period.

abolished in the pituitary of the $d w / d w$ rat (Gardi et al., 1999b). Takahashi et al. (1995) reported that GHRH-R mRNA is constitutively expressed in the rat hypothalamus. Our results support this finding. In addition, it seems that the short GHRH-R mRNA species is also the dominant isoform in the hypothalamus/preoptic region because the conditions used in our studies resulted in only one signal, which corresponded to the $\alpha$ subtype of the short transcript. (The primers used cannot amplify the $\beta$ subtype of the short GHRH-R mRNA isoform.) The significantly decreased GHRH-R mRNA levels reported here are the first indication that the GHRH signaling mechanism has the same defect in the hypothalamus/preoptic region as the previously described deficit in the pituitary of the $d w / d w$ rats.

In vitro observations suggest that the release of GHRH is enhanced in the $d w / d w$ rats (Bilezikjian et al., 1990). This phenomenon is attributed to the low GH concentration because GH/IGF-1 normally mediates negative feedback, inhibiting
GHRH production and release. Chronically enhanced release results in low GHRH content of the hypothalamus. Depletion of $\mathrm{GHRH}$ is observed in rats and mice with various $\mathrm{GH}$ deficiencies (Frohman et al., 1989; Kamegai et al., 1998) and in rats after hypophysectomy (Chomczynski et al., 1988; De Gennaro Colonna et al., 1988). Current findings demonstrate that the decrease in GHRH content also occurs in the hypothalamus of the $d w / d w$ rat.

Previously, we studied sleep in transgenic, GHRH-deficient, dwarf mice (Zhang et al., 1996). These mice bear a transgene composed of the promoter region of tyrosine hydroxylase and the coding region of the human $\mathrm{GH}$ gene ( $\mathrm{TH}-\mathrm{hGH}$ mice); thus, in these mice, tyrosine hydroxylase-positive neurons produce human GH (Banerjee et al., 1994). The high concentration of resulting intracerebral hGH acts as a negative feedback signal for the somatotropic axis by stimulating somatostatin and suppressing GHRH production (Szabo et al., 1995). Consequently, pituitary GH secretion is diminished and there is also a systemic IGF-1 deficiency. Only NREMS decreases in the TH-hGH mice (Zhang et al., 1996). In contrast, the $d w / d w$ rats displayed decreases in both spontaneous NREMS and REMS.

GHRH appears to have a selective NREMS-promoting activity, which is mediated by the preoptic region. This proposal is based on the observations that hypophysectomy (i.e., removal of $\mathrm{GH}$ ), fails to block GHRH-induced increases in NREMS (Obál et al., 1996) and that GHRH microinjected into the medial preoptic region selectively enhances NREMS (Zhang et al., 1999b). Decreases in central GHRHergic transmission may therefore explain the permanent NREMS loss in both the $d w / d w$ rat with GHRH-R deficiency and the TH-hGH transgenic dwarf mouse with suppressed production of GHRH. Nevertheless, in terms of sleep regulation, chronic decreases in GHRHergic activity might be in part compensated. An acute inhibition of GHRH blocks increases in both the duration and the intensity (EEG SWA) of NREMS during recovery sleep (Obál et al., 1992). In contrast, the deprivation-induced increases in the amounts of NREMS were normal, and only the enhancements in EEG SWA were attenuated during recovery in the $d w / d w$ rats. EEG SWA is an important marker of the activity of homeostatic sleep regulation (Borbély and Achermann, 1999). The current findings, therefore, suggest that normal functioning of the somatotropic axis is involved in this process. The absolute values and the diurnal variations of EEG SWA during spontaneous NREMS did not differ between the Lewis and the $d w / d w$ rats. Hence, only strong stimuli, such as sleep deprivation, may reveal the impairment of homeostatic sleep regulation. Alternatively, the GH deficiency may cause developmental alterations in the thalamocortical networks that are involved in the generation of SWA during NREMS. GH has been implicated in maturation of glia and neurons (Noguchi, 1996; Sekiguchi et al., 1998), but the morphological abnormalities occur predominantly in the cerebellum in GH-deficient animals, and we are not aware of alterations that can clearly be linked to the genesis of EEG waves. IGF-2 is the major IGF required for intrauterine growth and development, and unlike IGF-1, IGF-2 is not GH-dependent. Furthermore, the GH deficiency in newborn rats is not as severe as in adults because maternal milk contains GH-releasing factors different from GHRH, such as thyrotropin-releasing hormone, and thus the newborn $d w / d w$ rats respond with $\mathrm{GH}$ secretion to nursing (Kacsoh et al., 1999). It is noted that the NREMS responses and, in particular, the EEG SWA responses to sleep deprivation were unusually large in the Lewis rats. Lewis rats are 
characterized by a decreased stress responsiveness of the hypothalamic-pituitary-adrenal (HPA) axis (Sterberg et al., 1992; Baumann et al., 2000). This hormonal system mediates sleep suppression (for review, see Steiger and Holsboer, 1997). The amount of spontaneous NREMS is significantly higher in normal Lewis rats than in Sprague Dawley or Fisher rats (Opp, 1998). We are not aware of similar interstrain comparisons of recovery sleep, but the current findings suggest that the low HPA activity might be associated with an enhanced NREMS response to sleep deprivation in the Lewis rats.

Although the suppressed GHRHergic activity is the suggested major common candidate as the cause of the decreases in NREMS in both the $d w / d w$ rats and the TH-hGH mice, it is possible that the deficiencies in GH and IGF-1 also contribute. The effects of GH on NREMS are controversial, but some observations indicate that both GH and IGF-1 promote NREMS independently from GHRH (Aström and Lindholm, 1990; Obál et al., 1998). Theoretically, therefore, withdrawal of these hormones might be associated with reductions in NREMS. The TH-hGH mice, however, produce $\mathrm{GH}$ in the brain. The intracerebral $\mathrm{GH}$ is significant, as shown by the finding that $\mathrm{hGH}$ expressed exclusively in the cerebral cortex in another type of dwarf transgenic mice reaches the hypothalamus and inhibits GHRH (Hollingshead et al., 1989). Hence, we assume that deficiencies of GH or IGF-1 cannot provide a common clue for the decreases in NREMS in the $d w / d w$ rat and in the TH-hGH dwarf mouse.

In contrast to NREMS, REMS in the $d w / d w$ rats and the TH-hGH transgenic mice clearly differed; REMS decreased only in the $d w / d w$ rat. Although acute systemic or intracerebroventricular administration of GHRH may promote REMS, this response is not consistent and is likely to be an indirect action of GHRH (Obál et al., 1988). The effects of GHRH on NREMS and REMS can be separated, as shown by the preoptic GHRH microinjection that enhances NREMS without changes in REMS (Zhang et al., 1999b). Hypophysectomy, which does not alter GHRH-induced promotion of NREMS, abolishes increases in REMS in response to systemic GHRH injection (Obál et al., 1996). This finding may suggest that the presence of GH is necessary for stimulation of REMS by GHRH. GH is, in fact, capable of promoting REMS; increases in REMS are reported after acute administration of GH in rats (Drucker-Colin et al., 1975), cats (Stern et al., 1975), and humans (Mendelson et al., 1980), whereas immunoneutralization of $\mathrm{GH}$ is followed by decreases in REMS in rats (Obál et al., 1997). GH deficiency is often associated with decreases in REMS in children, but REMS might be normal in GH-deficient young adults (Orr et al., 1977; Hayashi et al., 1992). We suggest that the decreases in REMS result from the GH deficiency in the $d w / d w$ rat, whereas the intracerebral hGH compensates for the loss of pituitary $\mathrm{GH}$ and maintains normal REMS in the TH-hGH transgenic mouse. The mechanisms for GH effects on REMS remain unknown. Although GH may stimulate intracerebral production of IGF-1 (Sato and Frohman, 1993), IGF-1 is not involved in the REMS-promoting action because IGF-1 has no clear effects on REMS (Obál et al., 1998). Drucker-Colin et al. (1975) report that increases in REMS by systemic GH are closely associated with enhancements in protein synthesis in the CNS. GH is transported into the brain, in which it can modulate metabolism and neurotransmission (for review, see Nyberg and Burman, 1996).

In conclusion, after previous findings in GHRH-deficient THhGH transgenic mice (Zhang et al., 1996), the current results provide additional support for the importance of the somatotropic axis in sleep regulation. Chronic somatotropic deficiency is associated with permanent alterations in sleep in the rat.

\section{REFERENCES}

Aström C, Lindholm J (1990) Growth hormone-deficient young adults have decreased deep sleep. Neuroendocrinology 51:82-84.

Banerjee SA, Roffker-Tarlov S, Szabo M, Frohman L, Chikaraishi DM (1994) DNA regulatory sequences of the rat tyrosine hydroxylase gene direct correct catecholaminergic cell-type specificity of a human growth hormone reporter in the CNS of transgenic mice causing a dwarf phenotype. Mol Brain Res 24:89-106.

Baumann MH, Elmer GI, Goldberg SR, Ambrosio E (2000) Differential neuroendocrine responsiveness to morphine in Lewis, Fischer 344, and ACI inbred rats. Brain Res 858:320-326.

Beranek L, Hajdu I, Gardi J, Taishi P, Obál Jr F, Krueger JM (1999) Central administration of the somatostatin analog octreotide induces captopril-insensitive sleep responses. Am J Physiol 277:R1297-R1304.

Bilezikjian LM, Sutton SW, Otto S, Blount AL, Plotsky PM (1990) Characterization of the hypothalamic-somototrop axis in the dwarf rat. Presented at 72nd Annual Meeting of The Endocrine Society, Atlanta, GA, June.

Borbély AA, Achermann P (1999) Sleep homeostasis and models of sleep regulation. J Biol Rhythms 14:557-568.

Bradford MM (1976) A refined and sensitive method for the quantitation of microgram quantities of protein utilizing the principle of protein-dye binding. Anal Biochem 72:248-254.

Brain CE, Chomczynski P, Downs TR, Frohman LA (1991) Impaired generation of cyclic adenosine $3^{\prime}, 5^{\prime}$-monophosphate in a somatomammotroph cell line derived from dwarf (dw) rat anterior pituitaries. Endocrinology 129:3410-3416.

Carmignac DF, Robinson ICAF (1990) Growth hormone (GH) secretion in the dwarf rat: release, clearance and responsiveness to $\mathrm{GH}$ releasing factor and somatostatin. J Endocrinol 127:69-75.

Carmignac DF, Flavell DM, Robinson ICAF (1996) Pituitary growth hormone-releasing factor receptor expression in normal and dwarf rats. Neuroendocrinology 64:177-185.

Charlton HM, Clark RG, Robinson ICAF, Porter Goff AE, Cox BS, Bugnon C, Bloch BA (1988) Growth hormone-deficient dwarfism in the rat: a new mutation. J Endocrinol 119:51-58.

Chomczynski P, Downs TR, Frohman LA (1988) Feedback regulation of growth hormone $(\mathrm{GH})$-releasing hormone gene expression by $\mathrm{GH}$ in rat hypothalamus. Mol Endocrinol 2:236-241.

De Gennaro Colonna V, Cattaneo E, Müller EE, Maggi A (1988) Growth hormone regulation of growth hormone-releasing hormone gene expression. Peptides 9:985-988.

Downs TR, Frohman LA (1991) Evidence for a defect in growth hormone-releasing factor signal transduction in the dwarf (dw/dw) rat pituitary. Endocrinology 129:58-67.

Drucker-Colin RR, Spanis CW, Hunyadi J, Sassin JF, McGaugh JL (1975) Growth hormone effects on sleep and wakefulness in the rat. Neuroendocrinology 18:1-8.

Ehlers C, Reed TK, Henriksen SJ (1986) Effects of corticotropinreleasing factor and growth hormone- releasing factor on sleep and activity in rats. Neuroendocrinology 42:467-474.

Frieboes R-M, Murck H, Schier T, Holsboer F, Steiger A (1997) Somatostatin impairs sleep in elderly human subjects. Neuropsychopharmacology 16:339-345.

Frohman MA, Downs TR, Chomczynski P, Frohman LA (1989) Cloning and characterization of mouse growth hormone releasing hormone (GRH) complementary DNA: increased GRH messenger RNA levels in the growth hormone-deficient lit/lit mouse. Mol Endocrinol 3:1529-1536.

Gardi J, Obál Jr F, Fang J, Zhang J, Krueger JM (1999a) Diurnal variations and sleep deprivation-induced changes in rat hypothalamic GHRH and somatostatin contents. Am J Physiol 46:1339-1344.

Gardi J, Speth RC, Taishi P, Kacsoh B, Obál Jr F, Krueger JM (1999b) GHRH, GHRH receptor and sleep in the dw/dw dwarf rat. Presented at 81st Annual Meeting of the Endocrine Society, San Diego, CA, June.

Hayashi M, Shimohira M, Saisho S, Shimozawa K, Iwakawa Y (1992) Sleep disturbance in children with growth hormone deficiency. Brain Dev 14:170-174.

Hollingshead PG, Martin L, Pitts SL, Stewart TA (1989) A dominant phenocopy of hypopituitarism in transgenic mice resulting from central nervous system synthesis of human growth hormone. Endocrinology 125:1556-1564.

Kacsoh B, Bisat T, Guzzardo MB (1999) Regulation of growth hormone $(\mathrm{GH})$ secretion in neonatal $d w / d w$ dwarf rats by nursing, GH-releasing hormone $(\mathrm{GHRH})$, thyrotropin-RH $(\mathrm{TRH})$ and $\mathrm{GH}$-secretagogue (GHRP-6). Presented at 81st Annual Meeting of the Endocrine Society, San Diego, CA, June.

Kamegai J, Unterman TG, Frohman LA, Kineman RD (1998) Hypothalamic/pituitary-axis of the spontaneous dwarf rat: autofeed- 
back regulation of growth hormone $(\mathrm{GH})$ includes suppression of $\mathrm{GH}$ releasing-hormone receptor messenger ribonucleic acid. Endocrinology 139:3554-3560.

Katakami H, Downs TR, Frohman LA (1986) Decreased hypothalamic growth hormone-releasing hormone content and pituitary responsiveness in hypothyroidism. J Clin Invest 77:1704-1711.

Kerkhofs M, van Cauter E, Van Onderbergen A, Caufriez A, Thorner MO, Copinschi G (1993) Sleep-promoting effect of growth hormonereleasing hormone in normal men. Am J Physiol 264:E594-E598.

Kineman RD, Chen TT, Frawley S (1989) A cellular basis for growth hormone deficiency in the dwarf rat: analysis of growth hormone and prolactin release by reverse hemolytic plaque assay. Endocrinology 125:2035-2040.

Krueger JM, Obál Jr F, Fang J (1999) Humoral regulation of physiological sleep: cytokines and GHRH. J Sleep Res 8:53-59.

Lin C, Lin SC, Chang CP, Rosenfeld MG (1992) Pit-1 dependent expression of the receptor for growth hormone-releasing factor mediates pituitary cell growth. Nature 360:765-768.

Marshall L, Derad I, Starsburger CJ, Fehm HL, Born J (1999) A determinant factor in the efficacy of GHRH administration in promoting sleep: high peak concentration versus recurrent increasing slopes. Psychoneuroendocrinology 24:363-370.

Mayo KE (1992) Molecular cloning and expression of a pituitary-specific receptor for growth hormone-releasing hormone. Mol Endocrinol 6:1734-1744.

Mendelson WB, Slater S, Gold P, Gillin JC (1980) The effect of growth hormone administration on human sleep: a dose response study. Biol Psychiatry 15:613-618.

Miller TL, Godfrey PA, DeAlmeida I, Mayo KE (1999) The rat growth hormone-releasing hormone receptor gene: structure, regulation, and generation of receptor isoforms with different signaling properties. Endocrinology 140:4152-4165.

Mizobuchi M, Frohman MA, Downs TR, Frohman LA (1991) Tissuespecific transcription initiation and effects of growth hormone $(\mathrm{GH})$ deficiency on the regulation of mouse and rat $\mathrm{GH}$-releasing hormone gene in hypothalamus and placenta. Mol Endocrinol 5:476-484.

Müller EE, Locatelli V, Cocchi D (1999) Neuroendocrine control of growth hormone secretion. Physiol Rev 79:511-607.

Nistico G, DeSarro GB, Bagetta G, Müller EE (1987) Behavioural and electrocortical spectrum power effects of growth hormone releasing factor in rats. Neuropharmacology 26:75-78.

Noguchi T (1996) Effects of growth hormone on cerebral development: morphological studies. Horm Res 45:5-17.

Nyberg F, Burman P (1996) Growth hormone and its receptors in the central nervous system - location and functional significance. Horm Res 45:18-22.

Obál Jr F, Alföldi P, Cady AB, Johannsen L, Sáry GY, Krueger JM (1988) Growth hormone-releasing factor enhances sleep in rats and rabbits. Am J Physiol 255:R310-R316.

Obál Jr F, Payne L, Kapás L, Opp M, Krueger JM (1991) Inhibition of growth hormone-releasing factor suppresses both sleep and growth hormone secretion in the rat. Brain Res 557:149-153.

Obál Jr F, Payne L, Opp M, Alföldi P, Kapás L, Krueger JM (1992) Growth hormone-releasing hormone antibodies suppress sleep and prevent enhancement of sleep after sleep deprivation. Am J Physiol 263:R1078-R1085.

Obál Jr F, Floyd R, Kapás L, Bodosi B, Krueger JM (1996) Effects of systemic GHRH on sleep in intact and hypophysectomized rats. Am J Physiol 270:E230-E237.

Obál Jr F, Bodosi B, Szilágyi AA, Kacsoh B, Krueger JM (1997) Antiserum to growth hormone decreases sleep in the rat. Neuroendocrinology 66:9-16.

Obál Jr F, Kapás L, Bodosi B, Krueger JM (1998) Changes in sleep in response to intracerebral injection of insulin-like growth factor-1 (IGF-1) in the rat. Sleep Res Online 1:7-91.

Obál Jr F, Kapás L, Gardi J, Taishi P, Bodosi B, Krueger JM (1999) Insulin-like growth factor-1 (IGF-1)-induced inhibition of growth hormone secretion is associated with sleep suppression. Brain Res $818: 267-274$

Opp MR (1998) Rat strain differences suggest a role for corticotropinreleasing hormone in modulating sleep. Physiol Behav 63:67-74.

Orr WC, Vogel GW, Stahl ML, Griffiths WJ, Seely JR (1977) Sleep patterns in growth hormone deficient children and age-matched controls: developmental considerations. Neuroendocrinology 24:347-352.

Pellegrini E, Carmignac DF, Bluet-Pajot MT, Mounier F, Bennett P, Epelbaum J, Robinson ICAF (1997) Intrahypothalamic growth hormone feedback: from dwarfism to acromegaly in the rat. Endocrinology 138:4543-4551.

Perras B, Marshall L, Kohler G, Born J, Fehm HL (1999) Sleep and endocrine changes after intranasal administration of growth hormonereleasing hormone in young and aged humans. Psychoneuroendocrinology 24:743-757.

Sato M, Frohman LA (1993) Differential effects of central and peripheral administration of growth hormone $(\mathrm{GH})$ and insulin-like growth factor on hypothalamic GH-releasing hormone and somatostatin gene expression in GH-deficient rats. Endocrinology 133:793-799.

Sekiguchi M, Abe H, Moriya M, Tanaka O, Nowakowski RS (1998) Cerebellar microfolia and other abnormalities of neuronal growth, migration, and lamination in the Pit1dw-J homozygote mutant mouse. J Comp Neurol 26:363-374.

Steiger A, Holsboer F (1997) Neuropeptides and human sleep. Sleep 20:1038-1052.

Steiger A, Guldner J, Hemmeter U, Rothe B, Wiedemann K, Holsboer F (1992) Effects of growth hormone-releasing hormone and somatostatin on sleep EEG and nocturnal hormone secretion in male controls. Neuroendocrinology 56:566-573.

Sterberg EM, Glowa J, Smith M, Calogero AE, Listwak SJ, Aksentijevich S, Chrousos GP, Wilder RL, Gold PW (1992) Corticotropin-releasing hormone-related behavioral and neuroendocrine responses to stress in Lewis and Fischer rats. Brain Res 570:54-60.

Stern WC, Jalowiec JE, Shabshelowitz H, Morgane P (1975) Effects of growth hormone on sleep-waking patterns in cats. Horm Behav 6:189-196.

Szabo M, Butz MR, Banerjee SA, Chikaraishi DM, Frohman LA (1995) Autofeedback suppression of growth hormone $(\mathrm{GH})$ secretion in transgenic mice expressing a human $\mathrm{GH}$ reporter targeted by tyrosine hydroxylase 5' flanking sequences to the hypothalamus. Endocrinology 136:4044-4048.

Takahashi T, Okimura Y, Yoshimura K, Shigeyoshi Y, Kaji H, Abe H, Chihara K (1995) Regional distribution of growth hormone-releasing hormone $(\mathrm{GHRH})$ receptor mRNA in the rat brain. Endocrinology 136:4721-4724.

van Cauter E, Plat L (1998) Interrelations between sleep and the somatotropic axis. Sleep 21:553-565.

Zeitler P, Stevens P, Siriwardana G (1998) Functional GHRH receptor carboxyl terminal isoforms in normal and dwarf (dw) rats. J Mol Endocrinol 219:363-371.

Zhang J, Obál Jr F, Fang J, Collins BJ, Krueger JM (1996) Non-rapid eye movement sleep is suppressed in transgenic mice with a deficiency in the somatotropic system. Neurosci Lett 220:97-100.

Zhang J, Chen Z, Taishi P, Obál Jr F, Fang J, Krueger JM (1999a) Sleep deprivation increases rat hypothalamic growth hormone-releasing hormone mRNA. Am J Physiol 275:R1755-R1761.

Zhang J, Obál Jr F, Zheng T, Fang J, Taishi P, Krueger JM (1999b) Intrapreoptic microinjection of GHRH or its antagonist alters sleep in rats. J Neurosci 19:2187-2194. 